\title{
IMPACT OF SOWING DATES ON THE INFESTATION LEVEL OF SOME PIERCING-SUCKING PESTS AND YEILD OF CUCUMBER UNDER FAYOUM CONDITION
}

Abd EL-Wareth, H. M. and A. A. Abd El- Raheem

Plant Protection Research Institute, ARC, Dokki, Giza, 12618 Egypt

\begin{abstract}
The effect of sowing dates (March, $15^{\text {th }}$, April, $1^{\text {st }}$ and April, $15^{\text {th }}$ ) during summer plantation on the infestation level of, Aphis gossypii, Myzus persicae ,whitefly, Bemisia tabaci and spider mite, Tetranycus urticae and the yield of cucumber, Cucumis sativus, during two successive seasons (2014 and 2015) were studied. Data indicate that, the degree of infestation increased significantly by delaying planting date. The number of infestation with Aphids were $(8.2,11.1$ and 21.4 individuals/leaf) during 2014 season, (5.5, 9.1 and 22.0 individuals/leaf) during 2015 season for the three sowing dates, respectively. The average weight of cucumber fruit reached the highest $(180.0 \& 258.7 \mathrm{Kg} /$ date $)$ in the first season and $(191.7 \& 269.9 \mathrm{Kg} /$ date in the second season for the first sowing date for unprotected and protected, respectively. For the other two sowing dates, the infected levels for the other two pests , B. tabaci and T.urticae as well as the yield of cucumber were occupied the same trend.
\end{abstract}

Key words: Planting dates, cucumber, Aphis gossypii, Myzus persicae, Bemisia tabaci and Tetranycus urticae .

\section{INTRODUCTION}

Family: Cucurbitaceae represent an important part of vegetable production and was considered very important in agricultural crops in Egypt. The high production of cucurbit vegetables especially cucumber (Cucumis sativus L.) is of prime important aspect for local consumption and for export purposes Emam et.al.,(2006). This crop was infested by many pests, which are causing a considerable damage in either quantity or quality. They have established attacking by many important insect pests such as aphids, (Aphisgossypii Glover and Myzus persicae Sulzer), whitefly, Bemisia tabaci (Genn.) and spider mite, Tetranycus urticae Koch, El-Sayed et al., (1991). The immature and adult stages of these pests feed on phloem sap and excrete honeydew that hamper photosynthesis and render fruits unmarketable,

Fayoum J. Agric. Res. \& Dev., Vol. 30, No.1, January, 2016 
and they are efficient vectors of plant viruses, Booij (2003), Efil (2003), Sahu et al., (2005) and Hossain et al.,(2006) .

The aim of this study was to investigate, the optimum sowing date for cucumber.

\section{MATERIALS AND METHODS}

This study was conducted at Sennoris district; Fayoum Governorate during two summer plantation seasons of cucumber 2014 and 2015.The experimental area (about 1/4 feddan) was divided into two equal sections. Each section was divided into 12 plots, each plot was $6 \times 7 m=42 \mathrm{~m}^{2}(1 / 100$ feddan). Four replicates for each sowing dates were carried out and yield losses were estimated. Normal agricultural practices were followed for all treatments. The experimental was designed a randomized complete block design.

\section{A- Sowing dates:}

Seeds of cucumber, Cucumis sativus L. (El- Madinaa variety), Fam. Cucurbitaceae were sown in three planting dates at, March, $15^{\text {th }}$, April, $1^{\text {st }}$ and April, $15^{\text {th }}$, to study the relation between sowing dates and the infestation level for four pests Aphis gossypii Glover, Myzus persicae Sulzer, Bemisia tabaci (Genn.) and Tetranycus urticae Koch. Two weeks after planting, 10 leaves were picked randomly per plot every week, and the collected samples were kept in plastic bags and transferred to the laboratory for investigation and count it by using stereomicroscope.

\section{B- Yield losses:}

The second section was used to estimate the yield losses of unprotected in the three sowing date compared with those of protected. The protected plots were sprayed with chemical insecticide:

Scientific name: Thiamethoxam \% roWG

Commercial name: Actra (Syngenta product)

Chemical structure:(3-(2-chloro-thiazol-5-ylmethyl)-5-methyl-

[1,3,5] oxadiazinan-4-ylidene-N-nitroamine

Applied at: $80 \mathrm{gm} /$ feddan (according to Ministry of Agriculture and Land Reclamation 2015, MALR), for the control from seedling stage till ten days before harvesting (every 21 days). The yield of protected and unprotected plots were estimated using the formula of yield losses \%, according to (Hossain $\boldsymbol{e t}$ al.,(2006) as a following:

Percent losses in yield due to pests $=(\mathrm{X} 1-\mathrm{X} 2) / \mathrm{X} 1 * 100$

Where, X1: is the mean yield of protected plots

Fayoum J. Agric. Res. \& Dev., Vol. 30, No.1, January, 2016 
IMPACT OF SOWING DATES ON THE INFESTATION LEVEL

X2: is the mean yield of unprotected plots Statistical analyses of all treatments were analyzed according to, Duncan (1955)

\section{RESULTS AND DISCUSSION}

Results showed the lowest mean numbers of pests and highest yield were found during the $1^{\text {st }}$ sowing date. On the other hand, the highest mean numbers of pests and lowest yield were recorded during the $3^{\text {rd }}$ sowing date, for all pests under investigation during the two successive seasons, respectively.

\section{1) Population density of Aphis gossypii and Myzus persicae:}

Data presented in Table(1) and illustrated in Fugs $(1 \& 2)$ indicate that, the highest population density was occurred during the $10^{\text {th }}$ week for the $1^{\text {st }}$ sowing date being $(25.6 \& 25.9)$, during the $9^{\text {th }}$ week for the other two sowing dates, being $(39.4 \& 37.1)$ for the $2^{\text {nd }}$ sowing date and $(74.8 \& 71.4$ individuals/ leaf) for the $3^{\text {th }}$ sowing date, for the first and second seasons, respectively.

Data indicated that the population density of A. gossypii and Myzus persicae differed significantly according to the sowing date during the two successive seasons . In the first season, the population density of A. gossypii individuals increased by delaying planting date. The cucumber plants were sown in the earliest planting date infested significantly by the lowest mean number of aphids ( 8.2 individuals/ leaf). On the contrary, the plants of the last planting date harbored highest numbers of aphids (21.4 individuals/ leaf). In the second season, results took the same trend as obtained in the first season but were lower infestation rates than those recorded in the first season, being (5.5, 9.1 and 22.0 individuals/leaf) for the three sowing dates, respectively.

The present results are agreement with the findings of Helaly $\boldsymbol{e t}$. al. (1990) who reported that the population density of Aphis craccivora infesting cowpea varied significantly according to the time of sowing during summer plantation season. Hassanein (1994) recorded that the population density of A. craccivora was significantly affected by the time of sowing. He added that sowing date is an important factor for crop production as well as aphid infestation level. Metwally $\boldsymbol{e t .}$ al. (1994) indicated that the highest level of infestation by A. gossypii, A. craccivora and Myzus persica occurred in the late summer season than in winter, on common bean and squash. But it contrast with Shalaby (1998) who stated that the lowest infestation by $A$. craccivora and $M$. persicae on common bean occurred during the latest

Fayoum J. Agric. Res. \& Dev., Vol. 30, No.1, January, 2016 
Abd EL-Wareth, H. M. and A. A. Abd El-Raheem

planting date (March, 30 ${ }^{\text {th }}$ ) while, the earlier planting date (March, $1^{\text {st }}$ and $15^{\text {th }}$ ) harbored the highest number of aphids.

Table(1): Average numbers of, $A$. gossypii and $M$. persicae on cucumber through three sowing dates during the two seasons of 2014 and 2015 under Fayoum conditions.

\begin{tabular}{|c|c|c|c|c|c|c|}
\hline \multirow{3}{*}{ Weeks } & \multicolumn{7}{|c|}{$\mathbf{2 0 1 4}$} & \multicolumn{3}{c|}{$\mathbf{2 0 1 5}$} \\
\cline { 2 - 7 } & \multicolumn{7}{|c|}{ Mean numbers sowing dates } \\
\cline { 2 - 7 } & $\mathbf{1 5}^{\text {th }}$ March & $\mathbf{1}^{\text {st }}$ April & $\mathbf{1 5}^{\text {th }}$ April & $\mathbf{1 5}^{\text {th }}$ March & $\mathbf{1}^{\text {st }}$ April & $\mathbf{1 5}^{\text {th }}$ April \\
\hline 1 & 0 & 0.4 & 0.6 & 0 & 0.5 & 1 \\
\hline 2 & 1.2 & 0.9 & 0.9 & 0.3 & 0.8 & 2.9 \\
\hline 3 & 2.5 & 2.8 & 2.1 & 0.7 & 2.3 & 5.7 \\
\hline 4 & 3.8 & 4.6 & 5.3 & 2.8 & 7.7 & 6.4 \\
\hline 5 & 5.2 & 9.9 & 8.6 & 3.9 & 5.1 & 11.3 \\
\hline 6 & 8.4 & 7.1 & 21.2 & 2.4 & 6 & 24.9 \\
\hline 7 & 16.5 & 10.5 & 45.3 & 2 & 11.3 & 38.3 \\
\hline 8 & 12.1 & 27.8 & 59.9 & 6.1 & 23.9 & 56.1 \\
\hline 9 & 10.7 & 39.4 & 74.8 & 10.4 & 37.1 & 71.4 \\
\hline 10 & 25.6 & 26.1 & 34.6 & 25.9 & 16.4 & 33.1 \\
\hline 11 & 14.8 & 13.5 & 21.5 & 14.1 & 9.6 & 26.2 \\
\hline 12 & 9.3 & 8.4 & 13.1 & 6.2 & 4.2 & 19.5 \\
\hline 13 & 4.2 & 3 & 9.2 & 2.1 & 2.1 & 8.1 \\
\hline 14 & 1 & 1.3 & 2 & 0.3 & 0.9 & 2.1 \\
\hline Average & $8.2 \mathrm{a}$ & $11.1 \mathrm{~b}$ & $21.4 \mathrm{c}$ & $5.5 \mathrm{a}$ & $9.1 \mathrm{~b}$ & $22.0 \mathrm{c}$ \\
\hline
\end{tabular}

Mean in a column with different letters are significantly different $(\mathbf{P}<0.05)$

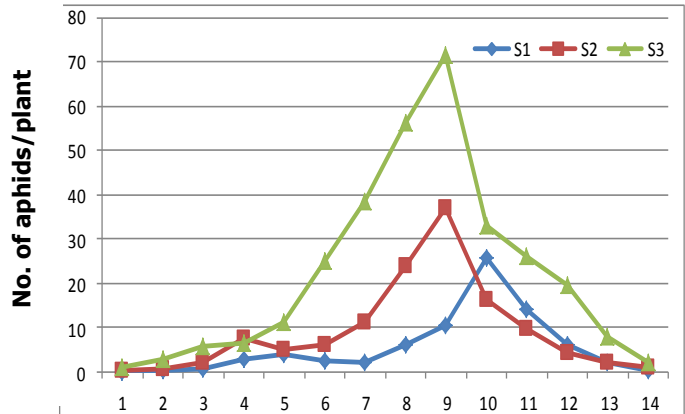

Weeks

Fig.(1): Seasonal abundance of aphids on cucumber plants for the three sowing dates during the first season 2014.

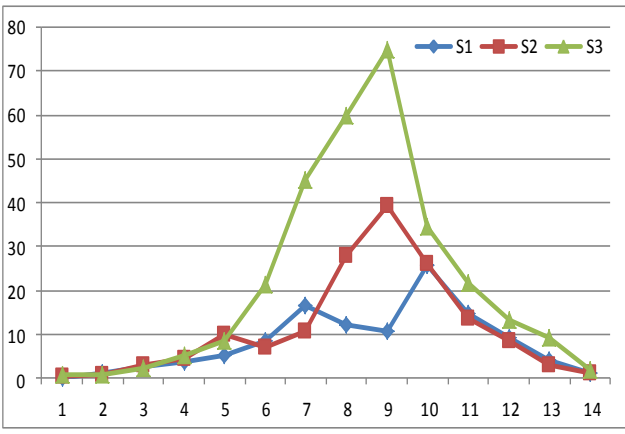

Weeks

Fig.(2):Seasonal abundance of aphids on cucumber plants for the three sowing dates during the second season 2015.

Fayoum J. Agric. Res. \& Dev., Vol. 30, No.1, January, 2016 
IMPACT OF SOWING DATES ON THE INFESTATION LEVEL

2) Population density of Bemisia tabaci:

Regarding the data recorded in Table (2) and illustrated in Figs ( $3 \& 4)$, its obviously clear that, the rates of infestation by $B$. tabaci nymphs to cucumber plants, planted in the three different dates took the same the trend aphids, i.e., increasing infestation as the planting date was delayed and one peak only for each sowing date during the two seasons. During the first season, the peak was occurred during the $8^{\text {th }}$ week for the three sowing date being, 3.2, 4.0 and 10.2 nymphs/leaf for the three dates, respectively.

But during the second season, the highest population density was occurred during the $7^{\text {th }}$ week for the $1^{\text {st }}$ and $2^{\text {nd }}$ sowing dates, but during the $9^{\text {th }}$ week for the $3^{\text {rd }}$ sowing date being 6.6, 13.3 and 23.9 nymphs/leaf for the three dates, respectively. During the two years, the heaviest infestation rates by $B$. tabaci nymphs were significantly, associated with planting on April15 $5^{\text {th }}$, as the seasonal mean counts were 10.2 and 11.3 nymphs/leaf for the two seasons, respectively. While the least mean number were recorded in the first sowing date being, 3.2 and 2.3 nymphs/ leaf for the two seasons, respectively. In a similar work on Helaly et. al., (1990) found that numbers of B. tabaci immature individuals occurred differently in different summer sowing dates of cowpea crop. El-Sayed $\boldsymbol{e t}$. al. (1991) revealed that the high rate of B. tabaci infestation different vegetable host plants were generally oriented to summer plantation, while the early summer plantation manifested lowest rate of infestation. Foda et. al. (1994) detected that the highest population density of B. tabaci adults and nymphs was occurred on pepper during late summer season ( $3^{\text {rd }}$ week of June), followed by summer $\left(3^{\text {rd }}\right.$ week of Feb.). Metwally et. al. (1994) recorded that the late planting dates of cucumber (June, $15^{\text {th }}$ ) harbored the higher numbers of B. tabaci immature stages than the earliest planting dates (Feb., $15^{\text {th }}$ and March, $15^{\text {th }}$ ). Emam et. al. (2006) on sweet pea plants in Egypt, as they reported that the infestation rate of $B$. tabaci increased by delaying planting date.

Fayoum J. Agric. Res. \& Dev., Vol. 30, No.1, January, 2016 
Abd EL-Wareth, H. M. and A. A. Abd El-Raheem

Table(2): Average numbers of, $B$. tabaci on cucumber through three sowing dates during the two seasons of 2014 and 2015 under Fayoum conditions.

\begin{tabular}{|c|c|c|c|c|c|c|}
\hline \multirow{3}{*}{ Weeks } & \multicolumn{7}{|c|}{$\mathbf{2 0 1 4}$} & \multicolumn{3}{|c|}{$\mathbf{2 0 1 4}$} \\
\cline { 2 - 7 } & \multicolumn{7}{|c|}{ Mean numbers sowing dates } \\
\cline { 2 - 7 } & $\mathbf{1 5}^{\text {th }}$ March & $\mathbf{1}^{\text {st }}$ April & $\mathbf{1 5}^{\text {th }}$ April & $\mathbf{1 5}^{\text {th }}$ March & $\mathbf{1}^{\text {st }}$ April & $\mathbf{1 5}^{\text {th }}$ April \\
\hline 1 & 0.4 & 0.82 & 2.0 & 0.0 & 1.5 & 1.2 \\
\hline 2 & 0.7 & 1.2 & 3.3 & 0.7 & 2.6 & 2.4 \\
\hline 3 & 1.2 & 1.9 & 5.2 & 0.9 & 3.5 & 3.5 \\
\hline 4 & 2.1 & 2.2 & 6.61 & 1.9 & 4.2 & 4.7 \\
\hline 5 & 2.5 & 3.5 & 10.8 & 2.4 & 6.2 & 6.1 \\
\hline 6 & 4.2 & 4.8 & 11.5 & 3.4 & 7.72 & 9.2 \\
\hline 7 & 5.6 & 6.1 & 13.4 & 6.6 & 13.3 & 14.0 \\
\hline 8 & 6.6 & 7.8 & 15.8 & 5.1 & 11.7 & 15.6 \\
\hline 9 & 5.5 & 10.5 & 21.5 & 3.3 & 8.7 & 23.9 \\
\hline 10 & 4.4 & 6.5 & 16.1 & 2.01 & 7.6 & 19.8 \\
\hline 11 & 4.3 & 4.8 & 13.0 & 1.9 & 6.3 & 11.6 \\
\hline 12 & 3.1 & 3.4 & 11.3 & 1.7 & 4.3 & 8.9 \\
\hline 13 & 2.3 & 1.3 & 7.8 & 1.3 & 2.1 & 2.8 \\
\hline 14 & 1.7 & 0.8 & 4.6 & 0.5 & 0.6 & 1.1 \\
\hline Average & 3.2 & 4 & 10.2 & 2.3 & 5.7 & 11.3 \\
\hline
\end{tabular}

Mean in a column with different letters are significantly different $(P<0.05)$

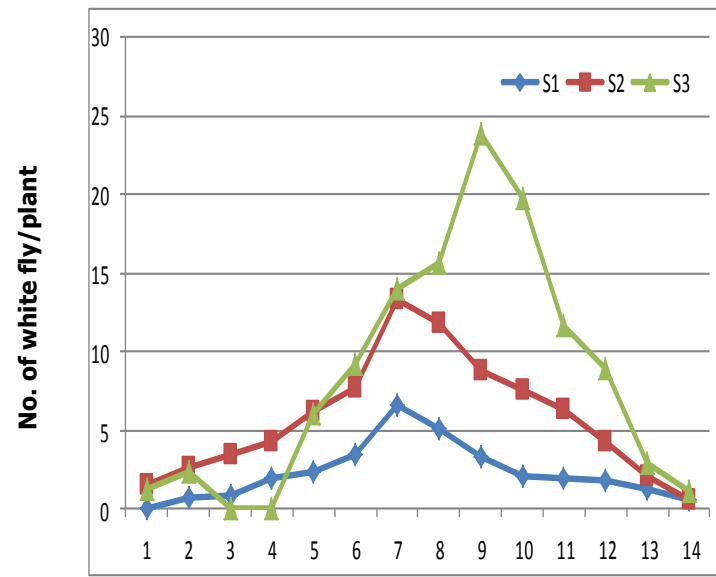

Weeks

Fig.(3): Seasonal abundance of white fly on cucumber plants for the three sowing dates during the first season 2014.

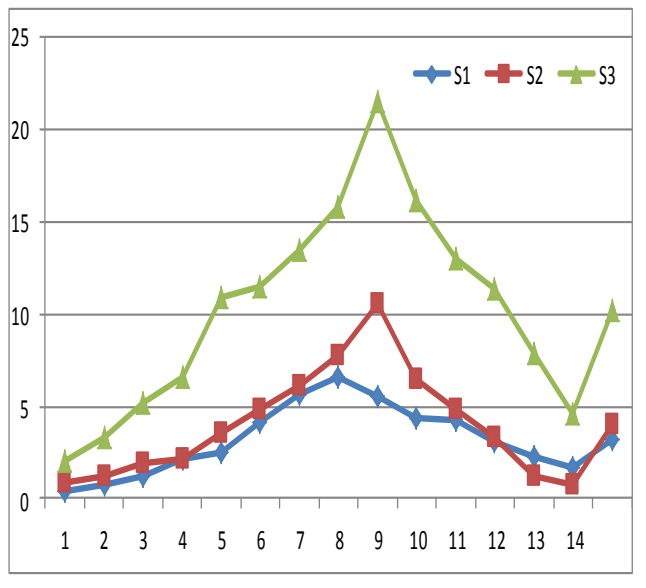

Weeks

Fig.(4): Seasonal abundance of white fly on cucumber plants for the three sowing dates during the first season 2015.

\section{3) Tetranycus urticae Koch:}

Data presented in Table (3) and illustrated in Fugs(5\&6) show that, The highest population numbers were noticed during the $8^{\text {th }}$ week after planting for the three dates of the first season being 62.8, 90.0 and 110.5

individuals/leaf, respectively. During the second season the peak was occurred

Fayoum J. Agric. Res. \& Dev., Vol. 30, No.1, January, 2016 
IMPACT OF SOWING DATES ON THE INFESTATION LEVEL

during the $7^{\text {th }}$ week for $1^{\text {st }}$ and $2^{\text {nd }}$ sowing dates and during the $8^{\text {th }}$ week for the $3^{\text {rd }}$ sowing date being 49.6, 81.5 and 125.7 individuals/leaf, respectively.

The rate of infestation by $T$. urticae to cucumber plants during the two successive seasons, increased by delaying planting date. As for the first planting date , cucumber leaves where the lowest seasonal mean count of T. urticae (24.5 and 20.8 individuals/leaf, respectively). On the contrary, the latest date recorded the highest infestation rate (44.1 and 53.3 individuals/leaf, respectively). Sowing date of (April $1^{\text {st }}$ ) being (37.3 and 30.5 individuals/leaf) led to intermediate rate of infestation, respectively. Statistical analysis proved that, the degree of infestation of T. urticae was significantly affected by sowing dates. In similar work Metwally et. al. (1994) recorded that the population density of $T$. urticae increased by delaying planting date on cucumber and common bean.

The present results agree with those of Emam $\boldsymbol{e t}$. al. (2006) on sweet pea plants, Geroh(2007) on okra, Fitzgerald et al., (2008) on strawberry, and Dutta et al., (2012) on cucumber as they reported that there was significantly less spider mites population on plants sown in the earliest planting date, while those sown in the latest planting date had the highest spider mites population.

Table (3): Average numbers of, $T$. urticae on cucumber through three sowing dates during the two seasons of 2014 and 2015 under Fayoum conditions.

\begin{tabular}{|c|c|c|c|c|c|c|}
\hline \multirow{2}{*}{ Weeks } & \multicolumn{7}{|c|}{ Mean numbers sowing dates } \\
\cline { 2 - 7 } & \multicolumn{3}{|c|}{$\mathbf{2 0 1 4}$} & \multicolumn{3}{|c|}{$\mathbf{2 0 1 4}$} \\
\cline { 2 - 7 } & $\mathbf{1 5}^{\text {th }}$ March & $\mathbf{1}^{\text {st }}$ April & $\mathbf{1 5}^{\text {th }}$ April & $\mathbf{1 5}^{\text {th }}$ March & $\mathbf{1}^{\text {st }}$ April & $\mathbf{1 5}^{\text {th }}$ April \\
\hline 1 & 4.3 & 5.5 & 6.8 & 3.3 & 5.8 & 7.8 \\
\hline 2 & 7.3 & 9.8 & 10.5 & 7.5 & 13.5 & 11.6 \\
\hline 3 & 8.8 & 10.4 & 17.8 & 11.8 & 25.7 & 25.7 \\
\hline 4 & 11.4 & 16.0 & 28.1 & 23.6 & 31.8 & 38.5 \\
\hline 5 & 35.8 & 35.6 & 60.7 & 29.6 & 50.5 & 62.4 \\
\hline 6 & 43.9 & 71.5 & 89.0 & 33.5 & 72.3 & 94.8 \\
\hline 7 & 55.6 & 77.3 & 100.2 & 49.6 & 81.5 & 110.5 \\
\hline 8 & 62.8 & 90.0 & 110.5 & 42.2 & 53.6 & 125.7 \\
\hline 9 & 37.5 & 68.4 & 87.4 & 38.3 & 31.4 & 88.8 \\
\hline 10 & 29.8 & 59.5 & 79.8 & 26.7 & 20.5 & 60.3 \\
\hline 11 & 21.9 & 38.6 & 59.6 & 12.0 & 16.7 & 44.5 \\
\hline 12 & 13.8 & 19.3 & 29.9 & 6.8 & 13.6 & 36.9 \\
\hline 13 & 7.5 & 15.0 & 17.0 & 4.3 & 7.8 & 27.8 \\
\hline 14 & 2.5 & 5.2 & 9.8 & 2.4 & 2.8 & 10.3 \\
\hline Average & 24.5 & 37.3 & 44.1 & 20.8 & 30.5 & 53.3 \\
\hline
\end{tabular}

Mean in a column with different letters are significantly different $(P<0.05)$

Fayoum J. Agric. Res. \& Dev., Vol. 30, No.1, January, 2016 


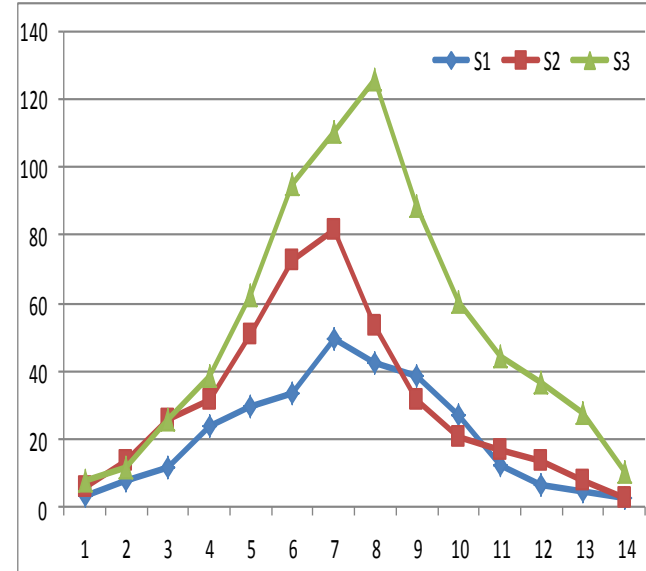

Weeks

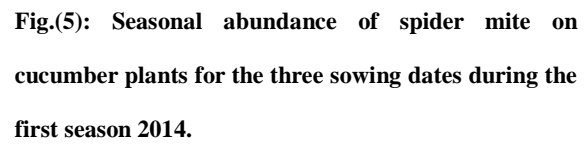

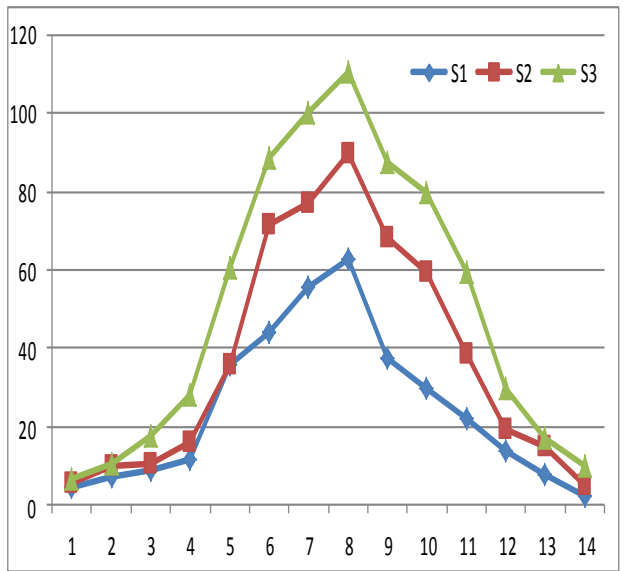

Weeks

Fig.(6): Seasonal abundance of spider mite on cucumber plants for the three sowing dates during the first season 2015.

\section{4) Effect of sowing dates on yield losses:}

Data presented in Table (4), indicate that the cucumber yield significantly higher in early sowing date for protected than unprotected plots. There was a highly significant difference between protected than unprotected inside the three sowing dates. The highest seasonal mean weight of cucumber in the first planting date being 219.4 and $230.8 \mathrm{~kg} /$ date but the lowest weight was occurred during the $3^{\text {rd }}$ sowing date being (143.0 and $138.9 \mathrm{~kg} /$ date) during the two successive seasons, respectively. For the second sowing date, yield occupied the intermediate level through out the two seasons, respectively. The yield losses were higher in the $3^{\text {rd }}$ date $(45.2$ and $47.4 \%)$ compared with the $1^{\text {st }}$ date being 30.4 and $29.0 \%$ during the two successive seasons, respectively. It could be concluded that the earliest planting date gave higher yield than that of other two planting dates.

The obtained results agree with those of, Bairwa et. al. (2005) on okra, who stated that earliest planting date, produced significantly highest weight of yield and Patil (2005) on brinjal who reported 38.81 percent reduction in number of fruits and 32.21 percent reduction in yield at highest release level of 200 T. macfarlanei per plant over control. Geroh (2011) reported that $T$. urticae was attacked okra plants negative values of correlation coefficients 
IMPACT OF SOWING DATES ON THE INFESTATION LEVEL

depicted a reciprocal relationship between mite population and various yield components due to T. urticae.

Table(4): Mean weight of yield per sowing date of cucumber during the two summer plantation seasons of 2014 and 2015.

\begin{tabular}{|c|c|c|c|c|c|c|c|c|}
\hline \multirow{3}{*}{$\begin{array}{c}\text { Sowing } \\
\text { Dates }\end{array}$} & \multicolumn{9}{|c|}{ First season } & \multicolumn{3}{|c|}{ Second season } \\
\cline { 2 - 9 } & $\begin{array}{c}\text { Un- } \\
\text { protected }\end{array}$ & Protected & $\begin{array}{c}\text { Mean } \\
\text { Kg/date }\end{array}$ & $\begin{array}{c}\text { Yield } \\
\text { losses }\end{array}$ & $\begin{array}{c}\text { Un- } \\
\text { protected }\end{array}$ & Protected & $\begin{array}{c}\text { Mean } \\
\text { Kg/date }\end{array}$ & $\begin{array}{c}\text { Yield } \\
\text { losses }\end{array}$ \\
\hline $1^{\text {st }}$ & $180.0 \mathrm{a}$ & $258.7 \mathrm{a}$ & 219.4 & $30.4 \mathrm{c}$ & $191.7 \mathrm{a}$ & $269.9 \mathrm{a}$ & 230.8 & $29.0 \mathrm{c}$ \\
\hline $2^{\text {nd }}$ & $128.7 \mathrm{~b}$ & $212.0 \mathrm{~b}$ & 170.4 & $39.3 \mathrm{~b}$ & $140.2 \mathrm{~b}$ & $223.5 \mathrm{~b}$ & 181.9 & $37.3 \mathrm{~b}$ \\
\hline $3^{\text {rd }}$ & $101.1 \mathrm{c}$ & $184.8 \mathrm{c}$ & 143.0 & $45.2 \mathrm{a}$ & $94.3 \mathrm{c}$ & $179.4 \mathrm{c}$ & 138.9 & $47.4 \mathrm{a}$ \\
\hline
\end{tabular}

Mean in a column with different letters are significantly different $(P<0.05)$

\section{REFERENCES}

Bairwa, D. K., P. M. Kanwat and K. C. Kumawat (2005). Effect of dates of sowing on the incidence of jassids, whiteflies and shoot fruit borer of the okra. Ann. Agric. Res., 26 (1): 110-112.

Booij, K. (2003). Dynamics of Thrips tabaci in diversified agro-ecosystems, a modeling approach. Bull. OILB/SROP, 26 (4): 19-24.

Duncan, D. B. (1955). Multiple range and multiple-F test. Biometrics, 11:142.

Dutta, N.K., S.N., Alam, M.K.Uddin, M.Mahmudunnabi and M.F.

Efil, L. (2003). The effect of different sowing dates to population's development of Thrips tabaci Lind. (Thysanoptera : Thripidae) in Hurran conditions. Ziraat Fakultesi Dergisi Ataturk Universities, 34 (1): 41-43.

El-Sayed, A. M., F. F. Shalaby, A. A. Abdel Gawad (1991). Ecological studies on Bemisia tabaci (Gennadius) (Hemiptera : Homoptera : Alyrodidae) infesting different host planting. I. Fluctuation and population density of Bemisia tabaci on different host plants. Egypt. J. Agric. Res., 69 (1): 193-207.

Emam, A. Z., M. F. A. H. Hegab and M. A. M. Tantawy ( 2006). Effect of planting space and date on the population densities of certain insect pests infesting sweet pea plants at Qalyoubia Governorate. Annl. Agric. Sci. Moshtohor, 44 (1): 299-308.

Farouk, S. and M.A. Osman (2011). The effect of plant defense elicitors on common bean (Phaseolus vulgaris L.) growth and yield in absence or

Fayoum J. Agric. Res. \& Dev., Vol. 30, No.1, January, 2016 
Abd EL-Wareth, H. M. and A. A. Abd El-Raheem

presence of spider mite (Tetranychus urticae Koch) infestation. $J$. StresscPhysio. and Biochem., 7(3): 6-22.

Fitzgerald, J., Xu X., Pepper, N., Easterbrook, M. and M. Solomon (2008). The spatial and temporal distribution of predatory and phytophagous mites in field-grown strawberry in the UK. Exp. Appl. Acarol., 44(4): 293-306.

Foda, M. E., M. Salem and B. M. Attia( 1994). Population dynamics of whitefly, Bemisia tabaci (Genn.) in certain vegetable crops in Egypt. J. Agric. Sci. Mansoura Univ., 19 (3): 1233-1243.

Geroh, M. (2007). Ecology and management of Tetranychus urticae Koch on okra, Abelmoschus esculentus L., Ph.D. Thesis, CCS HAU, Hisar.

(2011). Molecular Characterization of Beauveria bassiana (Balsamo) Vuillemin and its Bioefficacy against Tetranychus urticae Koch (Acari: Tetranychidae),Ph.D.Thesis, CCS HAU, Hisar.

Hassanein, S. S. M. (1994). Effect of some crop management practices on population of certain insects infesting broad bean plants at Khattara region, Egypt. Zagazig J. Agric. Res., 21 (6): 1807-1816.

Helaly, M. M., S. S. M. Hassanein and S. I. Yousif-Khalil (1990). Effect of sowing dates on cowpea infestation with certain pests at Zagazig, Egypt. Egypt. J. Appl. Sci., 5 (2): 64-76.

Helaly, M. M., S. S. M. Hassanein and S. I. Yousif-Khalil (1990). Effect of sowing dates on cowpea infestation with certain pests at Zagazig, Egypt. Egypt. J. Appl. Sci., 5 (2): 64-76.

Hossain, M.D.A., J. Ferdous and M. M. R. Salim (2006): Relative abundance and yield loss assessment of lentil aphid, Aphis craccivora Koch in relation to different sowing dates.J.Agric and Rural Development, 4(1\&2), 101-106.

Metwally, E. M., S. S. M. Hassanein and A. F. E. Afsa(1994). Effect of planting date on the population abundance of certain leaf pests infesting some vegetable crops at Gemmeza region, Egypt. Egypt J. Agric. Res., 72 (4): 977-988.

Patil, R.S. (2005). Investigation on mite pests of solanaceous vegetable with special reference to brinjal. Ph.D. Thesis, University of Agricultural Sciences, Dharwad.

Sahu, K. R., Y. K. Yadu and M. K. Chandrakar (2005). Impact of different dates of sowing the incidence of linseed thrips, Caliothrips indicus

Fayoum J. Agric. Res. \& Dev., Vol. 30, No.1, January, 2016 
IMPACT OF SOWING DATES ON THE INFESTATION LEVEL......... 39 (Bagnall) on linseed crop. Environ. and Ecol., 23 (special 2): 353355.

Shalaby, S. H. (1998). Studies on the principle insect pests attacking common bean in the field. M. Sc. Thesis, Fac. Agric., Moshtohor, Zagazig Univ., 93 pp.

$$
\begin{aligned}
& \text { تأثير مواعيد الزراعة علي مستوي الاصابة ببعض الأفات الثاقبة الماصة } \\
& \text { تحت ظروف محافظة الفيوم والمحصول علي نباتات الخيار } \\
& \text { حماده محمد عبد الحميد عبد الوارث و عبد الرحيم أحمد عبد الرحيم }
\end{aligned}
$$

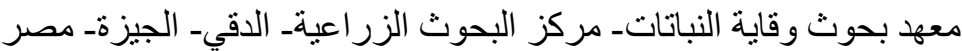

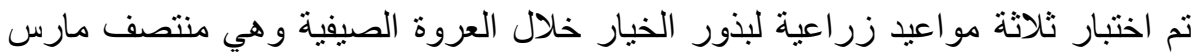

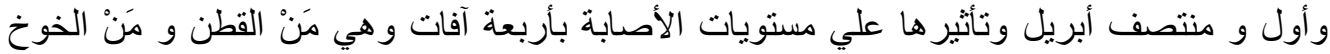

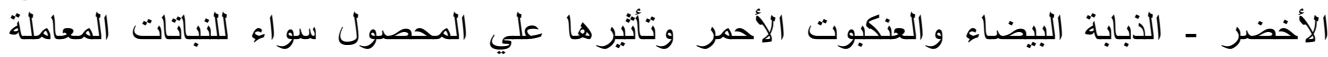

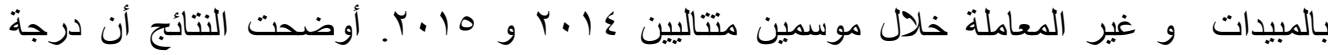

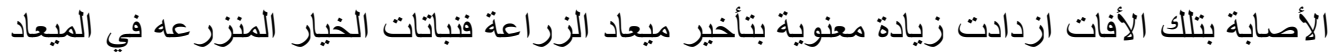

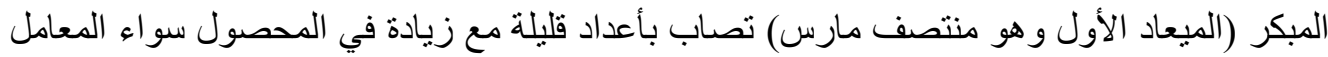

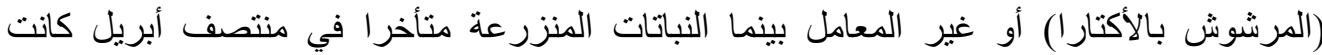

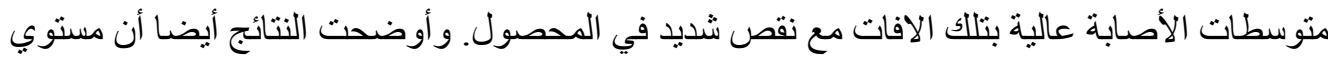

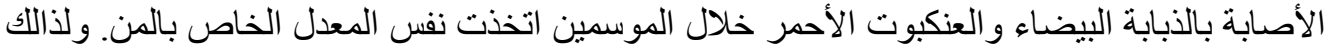

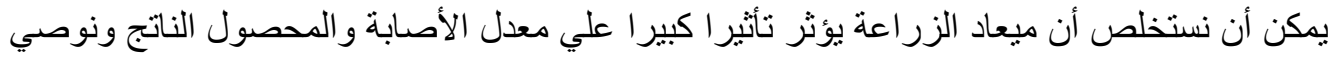
بالزر اعة منتصف مارس.

Fayoum J. Agric. Res. \& Dev., Vol. 30, No.1, January, 2016 